УДК 342

12.00.00 Юридические науки

КОРРУПЦИЯ - ФАКТОР УГРОЗЫ
ГОСУДАРСТВЕННОЙ БЕЗОПАСНОСТИ

Луговой Алексей Валерьевич

аспирант юридического факультета, Советник

Международной ассоциации детективов (IAPD), email:polevoy-77@yandex.ru

Санкт-Петербургский государственный

университет аэрокосмического приборостроения.

Россия, 190000, Санкт-Петербург, ул Большая

Морская, 67, лит. А, 8(812)710-65-10

В статье рассматриваются исторические причины и условия возникновения коррупции в России и некоторых зарубежных странах. Кратко исследовано понятие коррупции с точки зрения действующего законодательства, с целью предложения законотворческой инициативы в будущем расширить определение понятий: коррупционное поведение; коррупция; коррупционное правонарушение и преступление. В работе обозначены основные признаки коррупционного деяния, его разрушающее влияние на суверенитет и безопасность государства. Особое внимание обращено духовно-нравственной составляющей возникновения коррупционного поведения в обществе, а также его влияние на социальное, политическое, экономическое развитие государства. Исследование определяет разрушительную силу коррупционных проявлений как фактор дестабилизации экономической и политической жизни общества и страны, а также воздействие этого влияния на Международный авторитет и внешнюю безопасность государства. В статье на примере политических событий происходящих в странах дальнего и ближнего зарубежья, указано, что коррупция является основной причиной возникновения внутренних и внешних военных конфликтов. В работе определены предложения по усовершенствованию действующего антикоррупционного законодательства Российской Федерации, учитывая основные принципы верховенства закона, с целью недопущения внутренней и внешней дестабилизации в стране, а также для укрепления безопасности и Международного авторитета государства
UDC 342

Legal sciences

\section{CORRUPTION AS A STATE SECURITY THREAT}

Lugovoy Alexey Valerievich

graduate student of the Law Faculty

Advisor of the International Association of Detectives

(IAPD), e-mail: polevoy-77@yandex.ru

Saint Petersburg State University of Aerospace

Instrumentation

Russia, 190000, St. Petersburg, Bolshaya Morskaya, 67, lit. A, 8 (812) 710-65-10

The article deals with the historical causes and conditions of corruption in Russia and some foreign countries. The concept of corruption in terms of the current legislation is briefly studied with the aim of proposing legislative initiatives in future to expand the definition of concepts: corrupt behavior; corruption; corruption offense and a crime. The work outlines the key features of act of corruption, its devastating impact on the sovereignty and security of the state. Particular attention is paid to the spiritual and moral component of occurrence of corrupt behavior in society, as well as its impact on social, political and economic development of the state. The study determines the destructive force of corruption as a factor of destabilization of the economic and political life of the society and the country, as well as the impact of this effect on the international credibility and external security of the state. In the article on the example of the political events taking place in the countries of near and far abroad, it is stated that corruption is the main cause of internal and external wars. The article identifies proposals for the improvement of the current anticorruption laws of the Russian Federation, taking into account the basic principles of the rule of law, in order to prevent internal and external destabilization in the country, as well as to strengthen security and the international prestige of the state

Ключевые слова: КОРРУПЦИЯ,

Keywords: CORRUPTION, PUBLIC SECURITY, ГОСУДАРСТВЕННАЯ БЕЗОПАСНОСТЬ, БОРЬБА С FIGHTING WITH CORRUPTION, CORRUPT КОРРУПЦИЕЙ, КОРРУПЦИОННОЕ ПОВЕДЕНИЕ, BЕHАVIOR, ACTS OF CORRUPTION, ANTIКОРРУПЦИОННОЕ ДЕЯНИЕ, АНТИКОРРУПЦИОННАЯ ПОЛИТИКА, CORRUPTION POLICY, STATE, LAW, SOVEREIGNTY

Doi: 10.21515/1990-4665-124-071 
Коррупция в нашем обществе стала уже не столько криминальной проблемой, сколько общегосударственным негативным фактором, не только подрывающим авторитет власти, но и разрушающим государственность. Она способствует все более глубокому подрыву национальной безопасности. В целом, осознавая разрушительную силу коррупции, мы не представляем до конца, какую угрозу она несет для нормального функционирования всех институтов общественных отношений современного государства.

Понятие коррупция знакомо человечеству с древних времен. В мировой практике борьбы с коррупцией существует множество определений этого явления. Наиболее четкое определение коррупции дал в своих трудах Джозеф Сентурия : «З Злоупотребление публичной властью ради частной выгоды». Российская юридическая энциклопедия дает определение коррупции: « использование государственными служащими (чиновниками) и представителями органов государственной власти занимаемого ими положения, в силу своих служебных прав и властных полномочий для незаконного обогащения, получения и использования материальных преимуществ и иных благ, как в личных, так и в корыстных целях.[1.С 3841]

Статья № 1 Федерального закона «О противодействии коррупции » № 396 - ФЗ, определяет коррупцию как « злоупотребление служебным положением, дача взятки, получение взятки, злоупотребление полномочиями, коммерческий подкуп, либо иное незаконное использование физическим лицом своего должностного положения, вопреки законным интересам общества и государства в целях получения выгоды в виде денег, ценностей, иного имущества или услуг имущественного характера, иных имущественных прав для себя или для третьих лиц, либо незаконное предоставление такой выгоды указанному лицу другими физическими лицами, а также совершение вышеуказанных 
деяний от имени или в интересах юридического лица» [2.С. 25] Одним из множества признаков определений понятия коррупции, является возникновение господствующей власти немногих. Этот признак явно проявляется в разрушении правового регулирования всех общественных отношений любого государства, а в дальнейшем к невозможности регулирования международных общественных отношений. Примером этому является несанкционированные с $\mathrm{OOH}$ политические и военные мероприятия, проводимые на территории суверенных стран Азии, Евразии, Африки, такими крупнейшими странами как США, Англия, Германия.

Главным признаком коррупции, по мнению исследователей многих стран Мира, является доминирование власти немногих (олигархии). Так и в Мировом масштабе, нарушение норм международного права руководством отдельных развитых стран, приводит к развязыванию кровопролитных войн, геноциду мирного населения, общемировой экономической дестабилизации. Примером этому является политика США, Великобритании, Франции в отношении Ливии, Сирии, Украины и других стран.

Политика так называемых «двойных стандартов», доказала адекватно мыслящему мировому сообществу, что нормы Международного права реально не работают. По мнению некоторых политиков, деятельность служащих, занимающихся международно-правовыми вопросами, попала в список «ненужных мировых профессий». Общество осуждает обогащение небольшой горстки представителей элиты, будучи убежденным, и не без основания, что все их богатство нажито нечестным, незаконным путем. Повседневная «малая» коррупция воспринимается как неотъемлемая часть социальной реальности, но не как преступление, направленное против всего общества. Деформация жизненных ориентиров у значительной части россиян, особенно в подростковой среде, привела к тому, что стали признаваться социально одобряемыми некоторые формы аморального, 
антиобщественного и преступного поведения, не считаются позорными судимость, привлечение к уголовной ответственности. В сознании многих людей утрачена ценность продуктивного труда как источника благополучия и главного средства самореализации личности. Криминогенно значимые деформации духовно-нравственной сферы в значительной мере связаны со злоупотреблениями свободой слова в средствах массовой информации, пропагандой насилия и культа наживы любой ценой. В результате российские граждане, как и само правительство, действуют в этическом и моральном вакууме.[3.С 7-12].

Новая система постепенно скатилась к беспрецедентному для России распространению коррупции в социально-экономическую и политическую жизнь страны, а также положение дел с преступностью, не обходится без упоминания о коррупции.

Само понятие «коррупция» не имеет пока полного и исчерпывающего законодательного определения. Исследователи феномена коррупции во всем Мире так и не пришли к единому мнению относительно определения «коррупции» в целом. Так, до настоящего времени, не существует единого определения феномена «коррупции». Поэтому при постановке конкретного научного вопроса, выбирается такое понятие определения коррупции, которое в большей степени подходит для целей исследования. Расширить понятие «коррупции», поможет нам перевод с латинского самого слова - «corruptio». Где cor- переводится как сердце, душа, дух, рассудок. А ruptio - порча, разрушение, развращение. Если проанализировать вышеизложенное, то коррупцию следует определять, как совокупность общественно опасных деяний, направленных на разрушение экономической, политической, национальной безопасности страны, а в целом составляющие противоправные действия или бездействия направленные на подрыв государственного устройства Российской Федерации. 
Неотъемлемым объективным условием формирования правового государства является беспристрастное служение правовой системе, законным интересам своего народа. Коррупция является одним из наиболее опасных факторов общественной жизни, деструктивно влияющих на состояние национальной безопасности государства, и всех ее составных частей. Основная опасность коррупции, как антигосударственного, общественно опасного явления, заключается в разрушительном влиянии на устройство конституционных основ правового регулирования жизни общества. Прежде всего, это обусловлено тем, что деятельность коррумпированных государственных чиновников направлена на получение различного рода личных благ (в основном материальных), а не на обеспечение устойчивого и эффективного развития государственного устройства. Подобное положение дел ведет к снижению эффективности права и функционирования государства, напрямую противодействует его интересам в различных сферах деятельности, а в ряде случаев создает непосредственную угрозу безопасности граждан, общества, государства. Особую опасность коррупция представляет для политической, правовой, социальной и экономической жизни общества.[3. 7-12]

В России, так и в других странах мира, масштабы коррупции и возрастающая степень ее негативного влияния на развитие национальной экономики, требуют новой оценки в современных условиях.

Коррупция, как вид преступности, тесно переплетается с другими видами антиобщественных явлений. Она тесно связана с организованной преступностью, теневой экономикой и терроризмом, "подпитывает" их и "питается" от них. [4.C.5-36]

Коррупция влияет на снижение экономического роста, гражданского общества, нарушение прав человека, оказывает другие негативные 
воздействия на правовую систему. Само понятие "коррупция" имеет безусловную связь с деятельностью чиновников и потому может рассматриваться только исходя из определенных свойств, характеризующих это явление. Во-первых, это обязательно противоправная общественно опасная деятельность, направленная против национальных интересов государства; во-вторых, это обязательно организованная, обособленная от интересов государства деятельность облеченных государственной властью должностных лиц, состоящих на государственных или муниципальных должностях, в структурах аппарата государственной власти или, соответственно, в органах местного самоуправления; в-третьих, осуществление управленческой деятельности этих лиц неизменно связано со злоупотреблением своими должностными полномочиями и направлено на извлечение материальной прибыли в ущерб законным интересам всего общества. Исходя из указанных характерных особенностей, коррупцию следует рассматривать как самоуправляемую преступную организацию, в системе функционального государственного механизма, состоящую из чиновников государственной и муниципальной власти, объединенных целью незаконного извлечения материальной прибыли, удержания в своих руках политической и экономической власти с использованием своего государственно-властного положения, действующих в ущерб интересам безопасности государства. [4. С.5-36]

Рассматривая такое социальное явление, как коррупция, следует отметить, что это явление уходит своими корнями в глубокую древность. Истоки возникновения коррупции берут свое начало с возникновения первобытного общества. Древние люди, зависимые от сил природы, пытались задобрить богов, которые олицетворяли эти силы. Представителями богов являлись шаманы, колдуны и знахари, они же и получали подношения для расположения к обществу милости богов. Первый трактат с обсуждением коррупции - «Артхашастра» опубликовал 
под псевдонимом Каутилья один из министров Брахаты(Индия) в 4 веке до н.э. В нем он сделал вывод что «имущество царя не может быть, хотя бы в малости, не присвоено ведающими этим имуществом». Как считают некоторые ученые крупная коррупция всегда связана с возникновением олигархии (в переводе с греческого - «власть немногих). Возникновение коррупционных кризисов обуславливается, по мнению исследователей, развитием, так называемой глобализацией общественных отношений. Так на примере славянских народов и их взаимоотношений с Римом и Византией, можно выделить три механизма распространения коррупции: 1.прямой подкуп знати иностранными государствами; 2. участие в грабительских походах и войнах; 3. участие в международной торговле. Так Византия уничтожила Болгарское царство в 11 веке. В современный период, необходимо выделить и четвертый механизм распространения коррупции - прямое вмешательство влиятельных иностранных держав в развитии экономически неустойчивых государств. [5. C. 314-320]

В Шумерских клинописях, датируемых 3 - м тысячелетием до нашей эры, рассказывается о попытках Царя Урукагина пресечь попытки своего чиновничества вымогать у граждан страны «вознаграждения» за свои прямые обязанности. В свою очередь, в записях Вавилонского Царя Хаммурапи, датируемых второй половиной 19 века до нашей эры, сказано прямо: «.... Если судья, разобрал дело, вынес решение и изготовил документ с печатью, а затем решение свое изменил, то этого судью следует изобличить в изменении решения, которое он постановил, и исковую сумму, имеющуюся в этом деле, он должен уплатить в двенадцатикратном размере, кроме того, в собрании его должны согнать с его судейского кресла, и он не должен возвращаться и заседать вместе с судьями в суде.....». 
Множество упоминаний о коррупции встречается в трактатах древнеримских и древнегреческих политиков и философов. В «Двенадцати таблицах» ( законодательный свод Римской Республики-5 век до нашей эры) употребляется слово «corrumpere», которое обозначает подмену показаний в суде за деньги. Наиболее значительные масштабы коррупция приобрела в Европе в период времен Ренессанса. Прежде всего, причиной этому являлось активное развитие товарно-денежных отношений. Уважаемый и известный философ Фома Аквинский рассматривал коррупцию как неотъемлемую часть общества. Самый знаменитый случай средневековой коррупции связан с уничтожением знаменитого Ордена Тамплиеров. Король Франц Филипп Красивый сильно задолжал храмовникам, в результате чего сговорился с Папой Клементом 5 -м об истреблении Ордена и присвоении их богатств себе.[5.С.314-320]

В Нидерландах до 1698 года зарегистрировано огромное количество взяток и неконтролируемых сделок, пока один ушлый юрист Николас Майс Ван Хоули не добился того, чтобы все сделки регистрировались официально.

На Руси одно из первых законодательных оформлений борьбы против коррупционных действий приходится на период правления Ивана Грозного. Он впервые ввел смертную казнь в качестве наказания за чрезмерность во взятках и отменил систему «кормлений» в середине 16 века. «Кормленщиками» в ту пору называли доверенных лиц Князя или Государя на местах. Жалование им из казны не платилось, а содержать их были обязаны местные жители, с выплатой им в карман судебных и торговых пошлин.

Во времена правления Петра 1 на Руси также активно проводится борьба с коррупционными явлениями. Так для борьбы с казнокрадством на местах Петр 1 отряжал в волости своих комиссаров. За казнокрадство и взятки были повешены комиссары Арцибашев, Баранов, Волоцкий, которые 
занимались мздоимством в своих волостях. В целях эффективной борьбы с коррупцией, Петром 1 был основан орган - тайная канцелярия, в обязанность которого вменялся сбор информации о похищении казны. Дочь же Петра 1 - Царица Елизавета не уделяла внимание борьбе с коррупцией, она даже отменила смертную казнь за взяточничество.[5.С.314-320]

Активным приемником в антикоррупционной деятельности на Руси была Екатерина 2, она сразу же определила жалованье чиновникам. То, что мы сегодня называем взяткой, в юридическом языке 17 века имело несколько определений: «почести» - предварительные подарки должностному лицу решавшему вопрос; «поминки» - подарок по итогам решения вопроса; «посулы» - нарушение закона за плату. Так за посулы, были биты кнутом князь Алексей Кропоткин и дьяк Иван Семенов, взявшие деньги с купцов не желавших переселяться в Москву. Юридическим подтверждением активной борьбы с коррупцией того исторического периода являются копии указов. Петра 1 от 24 декабря 1714 года «О воспрещении взяток и посулов и о наказании за оное»........Дабы впредь плутам (которые стремятся лишь к тому, чтобы подложить мину под всякое доброе дело и удовлетворять свою несытость) невозможно было никакого оправдания сыскать, того ради запрещается всем чинам, которые у дел приставлены великих и малых, духовных, военных, гражданских, политических, купецких, художественных и прочих...... требовать никаких посулов казенных и с народа собираемых денег брать.....А кто рискнет это учинить, тот весьма жестоко на теле наказан, всего имущества лишен.... и из числа добрых людей извержен или смертью казнен будет....И дабы неведением никто не оговаривался, велеть всем стоящим у дел расписаться под этим указом..... а везде прибить печатные листы». В этом же Указе повышались денежные жалования чиновникам, был введен институт генерал- губернаторов, которым вменялись обязанности борьбы 
судебной волокитой, вплоть до отмены судебных решений. Таким образом, судебная власть отделена была от исполнительной.[5.С.314-320] В воинских Артикулах 1715 года были описаны должностные преступления: злоупотребление властью в корыстных целях; взяточничество; подделка денег, печатей, документов, срывание указов, принесение лжеприказов, лжесвидетельство, эти правонарушения отнесены в то время в раздел Артикула как « преступления против порядка управления и суда». Указом Екатерины 2 ,от 18 июля 1762 года « Об держании судей и чиновников от лихоимства»....... уже от давнего времени слышали много, а теперь и на деле увидели, до какой степени в государстве нашем лихоимство возросло, так, что едва ли есть самое малое место правительства, в котором.....суд без заражения этой язвой отправлялся. Ищет ли кто места - платит, защищается ли кто от клеветы обороняется деньгами, клевещет ли кто на кого - все происки свои хитрые подкрепляет дарами. Более того, многие судящие, освященное свое место, в котором они именем Нашим должны показывать правосудие, в торжище превращают, вменяя себе вверенное от звание судии....за пожалованный будто бы доход, в поправлении своего благосостояния, а не за службу, приносимую Богу, Нам и Отечеству, и мздоимством богомерзким, претворяют клевету в правдивый донос, разорение государственных доходов, в прибыль государственную, а иногда нищего делают богатым, а богатого - нищим.... Однако, сильное Наше на Бога упование и природное Наше великодушие, не лишают Нас еще надежды, чтоб все те, которые почувствуют от сего милосердного к ним напоминания ,некоторое в совести своей обличение, поймут, сколь великое зло есть в государственных делах мздоимство....Но если.... Увещание милосердное не подействует ..... то пусть они знают, что Мы направленные против этого зла законы .... впредь твердо исполнять будем .... не дав уже более милосердию Нашему места. Почему и никто, обвиненный в 
лихоимстве (ежели только жалоба до Нас дойдет праведная).... Не избежит Нашего гнева, так как Мы милость и суд в пути непорочном царствования Нашего народу ...».[5.С.314-320]

Времена правления императора Александра 2 оставили след в мировой истории борьбы с коррупцией, подтверждением этому были систематические публикации имущественного положения чиновников разного ранга. Источниками публикаций являлись книги « списки гражданским чинам определенного ведомства». В этих томах содержались .сведения о занимаемой должности чиновника, его жаловании, наградах, взысканиях, размере его имущества, также имущества его жены - как наследственное, так и приобретенное. Эти книги были общедоступны.

Александр 3 внес свою лепту в дело по борьбе с российской коррупцией. При его царствовании практически исчезли злоупотребления на железнодорожном транспорте. По его указу запрещалась практика эксплуатации железных дорог частными организациями. Результатами этих мер являлось то, что казна государства прекратила нести убытки, исчезали железнодорожные олигархи, которые сотрудничали с многими чиновниками. Сохраненные казенные деньги стали использоваться на строительство новых железных дорог, с введением единых тарифов на популярный в те времена железнодорожный транспорт.

При царствовании Николая 2 было создано новое Уголовное положение. В нем вводилось определение понятий «взяточничество» и «лихоимства». Но в начале 20 века произошел экономический подъем в Российской империи, в связи с этим количественный состав бюрократического аппарата возрос во время русско-японской войны. Росли военные заказы одновременно с частными сделками по продажи участков с полезными ископаемыми. Это вынудило царское правительство принять меры по усилению ответственности за получение взяток в военное время. За 
взяточничество отменялись всякие амнистии, сроки отбываются на каторге от звонка до звонка.

С началом 1 Мировой войны увеличилось количество коррупционных проявлений в рядах вооруженных сил, но времени и сил у действующей власти, на борьбу с ней - не хватало. Обострение внешнеполитического и внутриполитического кризиса в стране, под воздействием коррупционного влияния конкурирующих ведущих капиталистических стран мира, привело к изменению государственного устройства России.[5.С.314-320]

Усовершенствование борьбы с коррупцией на современном этапе развития нашего общества, является приоритетным направлением законотворчества в стране. На основании исследований многих ученых и анализа существующей практики борьбы с коррупцией, следует понимать, что под воздействием коррупционных проявлений, политические процессы каждого государства способны изменять свое развитие. Так политики, оказавшиеся под влиянием коррупционных схем, меняют свои решения и координируют мотивы своего поведения, не в пользу прогрессивного развития благосостояния общества в государстве, что подрывает государственную и Конституционную целостность страны. Мировой опыт показывает, что коррупция в больших масштабах, через рост недовольства может революционизировать граждан страны настолько, что они могут объединившись, свергать политический, конституционный строй в государстве. Такими «смутными» периодами могут воспользоваться коррумпированные, противоправно экономически заинтересованные политические режимы отдельных стран Мира, для достижения целей противоречащих нормам Международного права. Примером этому является международно-несанкционированное вмешательство США, Великобритании и ряда других развитых 
капиталистических стран Европы во внутренние дела Ирака, Египта, Ливии, Туниса.

Последние события в Украине открывают глаза Мировой общественности на новые, более страшные результаты воздействия коррупционных факторов, которые приводят не только к развязыванию «информационной» и Гражданской войны, но и к развитию новой «волны» национально-фашистского режима, и самого страшного - к человеческим жертвам. На основании анализа международнокоррупционных проявлений за последнее время, следует согласиться с тем, что коррупция в своем широком понимании, имеет степень общественной опасности, направленной не только против государственной власти, интересов государственной службы и службы в органах местного самоуправления, но в конечном итоге, против основ Конституционного строя и безопасности государства.

Огромную роль в возникновении коррупционных кризисов играет моральная деградация правящего класса. Со времен античности, та власть, которая провозглашала лозунги «обогащайся и властвуй», спустя даже столетия терпела крах. Следствие - наступление анархии в государстве. Главным воздействием противодействия коррупции является изменение сознания населения. Коррупция стала восприниматься не просто как нарушение закона, а опасность, угрожающая развитию государства. В то же время усилия, предпринимаемые обществом противодействию коррупции, не дают желаемых результатов.[4.С.5-36]

Среди других угроз национальной безопасности опрошенные эксперты назвали отставание государства от ведущих стран в сфере инноваций и модернизации, сокращение численности населения, сохранение экспортносырьевой модели экономики, терроризм, незаконный оборот наркотиков и оружия, низкое качество образования, а также отток специалистов за 
рубеж. При этом основной угрозой развития государства - является коррупция.[3.С.7-12]

Коррупция стала реальной угрозой национальной безопасности России. Своим размахом она сводит на нет или тормозит крупномасштабные экономические и социальные преобразования, проекты и непосредственно развитие государства. Коррупция расширяет сектор теневой экономики, уменьшает налоговые поступления в бюджет и делает неэффективным использование бюджетных средств. Коррупционные явления негативно влияют на международную репутацию страны в глазах ее политических и экономических партнеров. Тем самым ухудшается государственный инвестиционный климат. Увеличение имущественного неравенства граждан способствует формированию в общественном сознании представления о беззащитности граждан и перед преступностью и перед лицом власти. Коррупция является питательной средой для организованной преступности, терроризма и экстремизма. Она ускоряет процесс деградации моральных ценностей общества, исконных национальных традиций и обычаев.[6.51-53]

Государство является главным инструментом обеспечения национальной безопасности. Однако сам этот инструмент нуждается в обеспечении собственной безопасности. Для этого необходимо создавать новые рычаги и средства государственного управления, обеспечивающие оптимальное функционирование государства в системе государственной безопасности. ${ }^{7}$ Приоритетным методом противодействия коррупции в Российской Федерации выступает создание новой правовой системы, препятствующей совершению государственными служащими коррупционных сделок. Эта система включает введение обязательной независимой антикоррупционной экспертизы законопроектов с целью выявления наиболее типичных и формализованных проявлений коррупционности в 
тексте принимаемых законов, содержащие четкие термины, исключающих неоднозначные формулировки.

Учитывая приоритеты административно-правовой охраны общественных отношений в сфере обеспечения национальной безопасности, необходимо создать проект нормативного акта, в котором будут четко кодифицированы, определены и прокомментированы понятия - коррупция и коррупционное поведение, с учетом реформированных положений об антикоррупционной экспертизе.

На печальном примере сложившейся политической, экономической обстановке в Республике Украина отчетливо видно, как коррупционные процессы, влияют на государственную безопасность.

Начало этого необратимого процесса положено было после распада СССР. По причине разорванных экономических связей с братскими республиками, главное, с Российской Федерацией, новое руководство страны активно перестраивало экономику по европейской схеме. Конечно же, опыт экономического развития Европейских стран заслуживает положительной оценки. Но вышеуказанный опыт имеет свои национальные интересы и достижения, которые остаются их государственной собственностью.

Огромное количество предприятий и организаций, которые регистрировались в Украине в тот период, имели зарубежные активы, деятельность их была направлена на отток капитала из страны. Активно приватизировались объекты бывшей государственной собственности. Металлургические, машиностроительные, угледобывающие предприятия отчуждались из государственной собственности за номинально малые денежные средства. Способов мошенничества с приватизацией придумано было много. Эти противоправные действия, идущие в разрез с 
конституционными нормами государственного суверенитета, невозможно было совершать без использования коррумпированных связей, коррумпированного поведения и формирования коррупционной идеологии управления государством.

Вышеуказанная противоправная среда сформировала в Украине немногочисленную группу людей, которые сосредоточили на себе «власть немногих», то есть олигархию. Как правило, капитал этих людей вывозился из страны, а сами они постепенно стали политическими руководителями. Механизм продвижения олигархии в политическую элиту был внешне вполне законным, проводились выборы в ложно конституционной оболочке. Фальсификация избирательного процесса имела место почти во всех регионах. В последнее время избирательный процесс проводился очень часто и с нарушениями, что привело к утрате политического доверия населения к власти. Граждане Украины, в последнее время перестали активно посещать избирательные участки, что способствовало развитию коррупционной среды во внутренней и внешней политике страны.

Коррупционный режим в Украине привел к политической зависимости ее от развитых стран Европы и США. События в Киеве осенью-зимой 2013 года, является прямым подтверждением этому. Используя хаос в экономической, политической жизни страны, с учетом сформировавшейся коррупционной идеологии, специальные подразделения вышеуказанных стран используют и до настоящего времени события в Украине в своих геополитических целях. Результат - продолжительная гражданская война на юго-востоке страны, которая возможно войдет в историю как одна из самых жестоких войн. Для развязывания гражданской войны активно используются информационно-идеологические технологии, формируя у населения принцип двойных стандартов на очевидные факты. Люди одного 
вероисповедания, под воздействием активной пропаганды, уничтожают друг друга. Под воздействием коррупционных факторов в управлении государством, используются технологии националистического воспитания молодого поколения Украины. Неофашистские партии получили право голоса в Верховной Раде Украины, основного законодательного органа страны. Принимаются законы противоречащие принципам гуманизма, справедливости. За период с февраля 2014 года по настоящее время, погибли тысячи мирных граждан, в том числе безвинные дети. В стране бесчинствуют организованные бандитские формирования, которые не подчинены даже националистически настроенному новому правительству Украины. Фактически происходит геноцид мирного населения Республики Украина. Многие Украинские политологи и политики в последнее время выдвигают тезисы о том, что Украина под воздействием коррупционных процессов утратила свой суверенитет, а сохранила лишь номинальные признаки государственности. Проводя анализ воздействия коррупционных процессов на государственную безопасность, необходимо понимать, что возникла острая необходимость в законодательном расширении определения понятия коррупции в целом, принимая во внимание печальный опыт стран ближнего и дальнего зарубежья, необходимо кодифицировать и принять принципиально новые нормативные акты, регламентирующие борьбу с коррупцией во всех отраслях общественных отношений страны.

В 2015 году, Наша Страна, Общество и соседские Братские страны, праздновали 70 лет Победы в Великой Отечественной Войне. Нет в России и странах бывшего СССР семьи, в которой, война не оставила бы свой «черный след». Поэтому каждый гражданин остро понимает необходимость защиты государственного суверенитета и личной свободы, залогом которой будет формирование идеологии антикоррупционного поведения и совершенствование законодательной базы. 
Антикоррупционная политика Российской Федерации

Многонационального, Великого, Суверенного Государства развивается и будет продолжать прогрессивно развиваться на принципах верховенства закона, уважении к гражданам страны, сохранности государственной безопасности.

\section{Библиографический список:}

1.Мазурин С.Ф. Монография. Влияние коррупции на национальную безопасность государства // Государственная власть и местное самоуправление.- 2013.-№ 6.- С 38-41; 2.Закон Российской Федерации. О противодействии коррупции. № 396-ФЗ от 28.12.13 г. C-25;

3.Шерстобитов В.Ю. Национальная и международная безопасность: основы и проблемы в Российской Федерации. Коррупция как угроза национальной безопасности // Изд-во Российская таможенная академия. М. С 7-12;

4.Хабибулин А.Г. Коррупция как угроза национальной безопасности: методология, проблемы и пути их решения. // Журнал Российское право 2007 г. Юридическая электронная библиотека. ЮРИСТЛИБ. С-5-36;

5.Луговой А.В. Генезис коррупции в России. Научная сессия ГУАП: сб. докл.: в 3 ч. Ч. III. Гуманитарные науки. СПб.: ГУАП, 2014. 378 с.: ил. С 314-320;

6. Челпаченко О.А. Коррупционные проявления как угроза национальной безопасности: Новый индекс. М.2010.С 51-53.

\section{References}

1.Mazurin S.F. Monografija. Vlijanie korrupcii na nacional'nuju bezopasnost' gosudarstva // Gosudarstvennaja vlast' i mestnoe samoupravlenie.- 2013.-№ 6.- S 38-41;

2.Zakon Rossijskoj Federacii. O protivodejstvii korrupcii. № 396-FZ ot 28.12.13 g. S-25;

3.Sherstobitov V.Ju. Nacional'naja i mezhdunarodnaja bezopasnost': osnovy i problemy v Rossijskoj Federacii. Korrupcija kak ugroza nacional'noj bezopasnosti // Izd-vo Rossijskaja tamozhennaja akademija. M. S 7-12;

4.Habibulin A.G. Korrupcija kak ugroza nacional'noj bezopasnosti: metodologija, problemy i puti ih reshenija. // Zhurnal Rossijskoe pravo 2007 g. Juridicheskaja jelektronnaja biblioteka. JuRISTLIB. S-5-36;

5.Lugovoj A.V. Genezis korrupcii v Rossii. Nauchnaja sessija GUAP: sb. dokl.: v 3 ch. Ch. III. Gumanitarnye nauki. SPb.: GUAP, 2014. 378 s.: il. S 314-320;

6. Chelpachenko O.A. Korrupcionnye projavlenija kak ugroza nacional'noj bezopasnosti: Novyj indeks. M.2010.S 51-53. 